\title{
Morphological Characteristics of European Slalom Canoe and Kayak Paddlers
}

\author{
Características Morfológicas de los Remeros de Canoa y Kayak de Slalom Europeos
}

\author{
Klára Coufalová1; Jan Busta ${ }^{1}$; Darryl James Cochrane ${ }^{2}$ \& Milan Bíly ${ }^{1}$
}

\begin{abstract}
COUFALOVÁ, K.; BUSTA, J.; COCHRANE, D. J. \& BÍLY, M. Morphological characteristics of European slalom canoe and kayak paddlers. Int. J. Morphol., 39(3):896-901, 2021.
\end{abstract}

SUMMARY: The primary aim of this study was to determine the morphology of elite canoe slalom paddlers and to identity if morphology differences existed between kayak and canoe paddlers. The survey included a total of 74 canoe slalom paddlers who competed in the 2018 European Championship. These competitors were assessed using a battery of anthropometric dimensions according to standardized anthropometric techniques and bioimpedance analysis using the multifrequency octopolar device Tanita MC-980. Elite slalom male competitors can be characterized to having average body height $(\sim 180 \mathrm{~cm})$, average weight $(\sim 75 \mathrm{~kg})$, with ectomorphic mesomorph somatotype $(1.3-5.5-2.7)$, well developed trunk and arm muscles (biceps girth: $35.4 \pm 1.8)$, low hypertrophy of legs and low body fat $(8 \pm 3.2 \%)$. In addition, there are no significant differences between canoe $(\mathrm{C} 1)$ and kayak (K1) paddlers. For female competitors we can conclude, there has been little change in anthropometric values through the decades. However, $\mathrm{C} 1 \mathrm{competitors}$ are younger, more mesomorphic and less ectomorphic.

KEY WORDS: Anthropometry; Bioelectrical impedance; Somatotype; Kayak slalom; Canoe slalom.

\section{INTRODUCTION}

Canoe slalom is a timed event where competitors navigate a whitewater course by passing through a combination of upstream and downstream 'gates' consist of two poles suspended above the water. Each course variesup to a maximum of $300 \mathrm{~m}$ in length and a maximum of 25 gates, with a minimum of six upstream gates. Depending on the course design international athletes will complete racing in 90 to 110 seconds. Overall race performance is determined by the time to complete plus penalties gained for touching ( 2 seconds) or missing a gate (50 seconds). Canoe slalom is contested in two types of boat, canoe and kayak. In canoe slalom the athlete uses a single-blade paddle and is strapped into the boat with their knees bent and tucked under their body. In contrast, in kayak slalom the athlete is seated and uses a double-bladed paddle. Male and female athletes compete in individual kayak (K1) and individual canoe $(\mathrm{C} 1)$ races.

Canoe slalom relies on the muscles of the upper limbs and trunk to create the necessary boat propulsion and to navigate it in and out of gates, which requires an appropriate level of muscular strength and power. Anthropometric measures of Olympic paddlers revealed body height and body weight were average for male $(177 \pm 7 \mathrm{~cm} ; 72.5 \pm 5.8$ $\mathrm{kg}$ ) in comparison to a reference population of non-athletes and above average for females $(168 \pm 5 \mathrm{~cm} ; 59 \pm 4.5 \mathrm{~kg})$ (Ridge et al., 2007). Chest girth measurement for males and females have been recorded at $102.9 \pm 4.1 \mathrm{~cm}, 91.0 \pm 3.6$, respectively and were $35.0 \pm 1.6 \mathrm{~cm}$ and $30.1 \pm 1.0 \mathrm{~cm}$ for flexed arm girth in males and females, respectively (Ridge et al.). Male and female slalom athletes are considered predominantly mesomorphic (Ridge et al.). A recent study, however, reported that international male canoeists body weight (76.2 \pm 4.4$)$, somatotype $(1.4-5.6-2.3)$ and girth of flexed arm (35.6 \pm 1.5$)$ (Busta et al., 2018) were different to that of earlier research (Ridge et al.).

The difference between the above two studies suggest that the morphology of competitors may have changed over the last 11 years. Due to the development of canoe slalom in the last quarter century (shortening of courses, improvement of materials and boats, improved physical conditioning and coaching) it is likely that the athletes' morphology has

\footnotetext{
${ }^{1}$ Charles University, Faculty of Physical Education and Sport, José Martího 31, 16252, Prague, Czech Republic.

${ }^{2}$ School of Sport and Exercise, Massey University, Palmerston North 4442, New Zealand.
} 
changed. It is plausible that morphology changes in the body parameters may be related to strength, speed and power attributes for canoe slalom. To determine possible changesa similar representative research sample is required to compare Ridge et al. data with current slalom athletes. The primary objective of this study was to determine the morphology of canoe slalom paddlers that competed in the 2018 European Championship. A secondary objective, was to identity if morphology differences existed between kayak and canoe paddlers, which included an assessment of body composition analysis to determine body fat percentage.

\section{MATERIAL AND METHOD}

Participants. Seventy-four competitors from the 2018 Canoe Slalom European Championship were assessed using a battery of anthropometric dimensions and bioimpedance analysis. From 48 male paddlers, 23 competed in canoe events and 25 in kayak events. From 26 female paddlers, 11 competed in canoe events and 15 in kayak events. According to the rules for canoe slalom international events, only 3 competitors of the same country for each category can start at the European Championship. Therefore, the sample population verifies an elite or sub-elite level of competitors. Athletes were contacted and invited to take a part in this study through team officials during a team leaders meeting. Specific rules for measurements were given. All participants read and signed a consent form before testing and the study was approved by the university ethical committee.

Data collection. Two days prior to the European Championship event, paddlers were assessed on consecutive days. To eliminate inter-rater variability, all measurements were conducted by a single experienced examiner. Licensed anthropometric instruments were used for data collection and anthropometric measurements were performed according to techniques suggested by the Anthropometric Standardization Reference Manual (Lohman et al., 1988). Arm span was measured in standing position with the arms fully extended. The distance between the tips of the stretched middle fingers was taken. Sitting height is a measurement of the distance from the highest point on the head to the base sitting surface when the subject sits with both feet on the floor, the lower back and shoulders against the wall, looking straight ahead. Shoulder breadth, the distance between the lateral margins of the acromion processes, was measured using breadth caliper. Other breadth measurements were made by a specific breadth measurement calipers. Other anthropometric parameters (forearm girth, flexed arm girth, chest, thigh, calf girth) were measured according to techniques suggested by the
Anthropometric Standardization Reference Manual. We measured skinfold thicknesses (triceps, subscapular, suprailiac, thigh and calf skinfold) to determine somatotype. We used caliper type BEST K-501 (Trystom, CZE). Measurement of skinfold thicknesses were completed once on the right site of the body. Somatotypes were calculated according to Heath \& Carter (1990). Body fat was evaluated using the multifrequency octopolar device Tanita MC-980 (Tanita Co., Tokyo, Japan) using 1, 5, 50, 250, 500 and $1000 \mathrm{kHz}$, which measured whole-body bioimpedance. The participant's age, sex and height were entered into the device. Participants were asked not to eat for 2 hours and drink 1 hour before the measurement. Testing was performed in a standing position with arms extended down. The calculation of body fat percentage was determined from the prediction equation supplied by the manufacturer (Biospace Co., Ltd., Korea).

Data analysis. Descriptive statistics of male and female data were used to compare canoe and kayak paddlers. To determine differences between the groups an independent student's T-test was used. Statistical significance was set at $p<0.05$ and to determine practical differences between canoe and kayak paddlers Cohen's d was calculated. Effect sizes were classified as trivial $(0-0.2)$, small $(0.2-0.6)$, moderate $(0.6-1.2)$, large $(1.2-2.0)$ and very large $(>2.0)$ (Hopkins, 2006).

\section{RESULTS}

Table I illustrates the age, body mass, height, body mass index, anthropometric dimensions, bioimpedance analysis of male $(n=48)$ and female $(m=26)$ European canoe slalom athletes. Table II shows the comparison between male and female canoe and kayak athletes. For male canoe and kayak paddlers there was no significant difference $(p>0.05)$ in age, body mass, height, body mass index, anthropometric dimensions and bioimpedance analysis. Similarly, for females there was no significant difference $(p>0.05)$ between canoe and kayak paddlers in body mass, height, body mass index and bioimpedance analysis. There was a significant difference in age $(p=0.04, d=0.83)$, morphological categories of mesomorphy $(\mathrm{p}=0.02, \mathrm{~d}=0.93)$, and ectomorphy $(\mathrm{p}=0.03, \mathrm{~d}=0.80)$.

Figures 1 and 2 show somatographs of individual canoe (C1) and kayak (K1) men paddlers, the individual somatotypes and also average somatotype. Figures 3 and 4 show somatographs of individual canoe (C1) and kayak (K1) women paddlers, the individual somatotypes and also average somatotype. 
Table I. Morphology of male and female European paddlers.

\begin{tabular}{lrccc}
\hline Variable & \multicolumn{2}{c}{ Male paddlers $(n=48)$} & \multicolumn{2}{c}{ Female paddlers $(n=26)$} \\
& Mean \pm SD & Range & Mean \pm SD & Range \\
\hline Age (years) & $24.3 \pm 4.8$ & $15-36$ & $23.7 \pm 6.9$ & $16-46$ \\
Body mass $(\mathrm{kg})$ & $74.8 \pm 6.2$ & $56.5-85.3$ & $58.8 \pm 4.6$ & $51.4-68.4$ \\
Height $(\mathrm{cm})$ & $179.8 \pm 5.1$ & $167.1-193.5$ & $164.2 \pm 5.4$ & $154.2-173.1$ \\
Body mass index & $23.1 \pm 1.5$ & $19.4-26.2$ & $21.8 \pm 1.4$ & $19.6-25.1$ \\
Sitting height $(\mathrm{cm})$ & $94.7 \pm 3.9$ & $83.5-103$ & $88.4 \pm 3.0$ & $83.2-95$ \\
Arm span $(\mathrm{cm})$ & $184.5 \pm 6.3$ & $170-195.6$ & $165.0 \pm 6.9$ & $152-180$ \\
Sitting height/body height $(\%)$ & $51.5 \pm 1.5$ & $46.2-55.8$ & $53.5 \pm 1.9$ & $0.47-0.59$ \\
Arm span/body height $(\%)$ & $102.6 \pm 2.8$ & $94.3-111.1$ & $100.5 \pm 1.9$ & $96.5-104.0$ \\
Shoulder breadth $(\mathrm{cm})$ & $36.0 \pm 2.1$ & $32-39.7$ & $30.8 \pm 1.1$ & $29.2-33.9$ \\
Humerus breadth $(\mathrm{cm})$ & $7.2 \pm 0.4$ & $6.3-8.7$ & $6.2 \pm 0.4$ & $5.5-6.9$ \\
Femur breadth $(\mathrm{cm})$ & $10.1 \pm 0.6$ & $8.7-12$ & $9.1 \pm 0.4$ & $8.5-10.2$ \\
Forearm girth $(\mathrm{cm})$ & $28.9 \pm 1.3$ & $25.5-31.4$ & $25.0 \pm 0.9$ & $23.2-26.8$ \\
Flexed arm girth $(\mathrm{cm})$ & $35.4 \pm 1.8$ & $31.5-38.4$ & $30.6 \pm 2.1$ & $28.3-38.0$ \\
Chest girth $(\mathrm{cm})$ & $101.6 \pm 5.2$ & $85.5-110.3$ & $90.9 \pm 3.7$ & $81-99$ \\
Thigh girth $(\mathrm{cm})$ & $50.3 \pm 3.5$ & $40.9-50.6$ & $49.9 \pm 3.3$ & $43.1-54.9$ \\
Calf girth $(\mathrm{cm})$ & $36.1 \pm 1.8$ & $32-41.5$ & $34.9 \pm 2.2$ & $30.4-40.1$ \\
Sum of 5 skinfolds $(\mathrm{mm})$ & $32.8 \pm 7.1$ & $20-47$ & $54.0 \pm 13.0$ & $39-95$ \\
Body fat $(\%)$ & $8.0 \pm 3.2$ & $3-16.2$ & $17.0 \pm 4.3$ & $10-26.6$ \\
Endomorphy & $1.3 \pm 0.3$ & $0.6-2.1$ & $2.5 \pm 0.8$ & $1.3-4.8$ \\
Mesomorphy & $5.5 \pm 0.9$ & $3.9-7.8$ & $4.8 \pm 0.9$ & $3.3-6.6$ \\
Ectomorphy & $2.7 \pm 0.8$ & $1.3-4.6$ & $2.4 \pm 0.8$ & $0.9-3.8$ \\
\hline
\end{tabular}

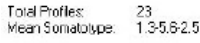

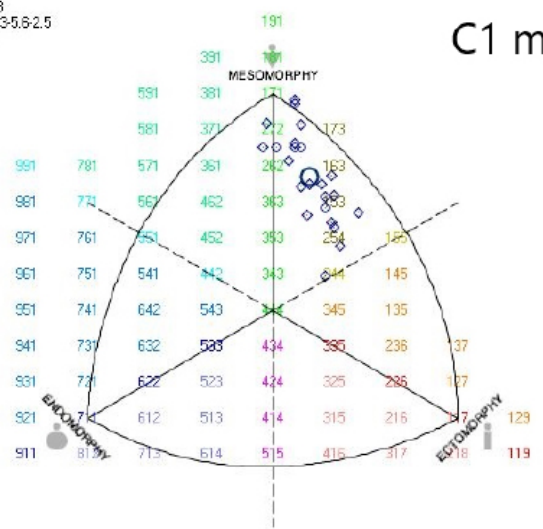

Fig. 1. Somatograph of $\mathrm{C} 1$ men paddlers: $\diamond$ individual somatotype; ? average somatotype.

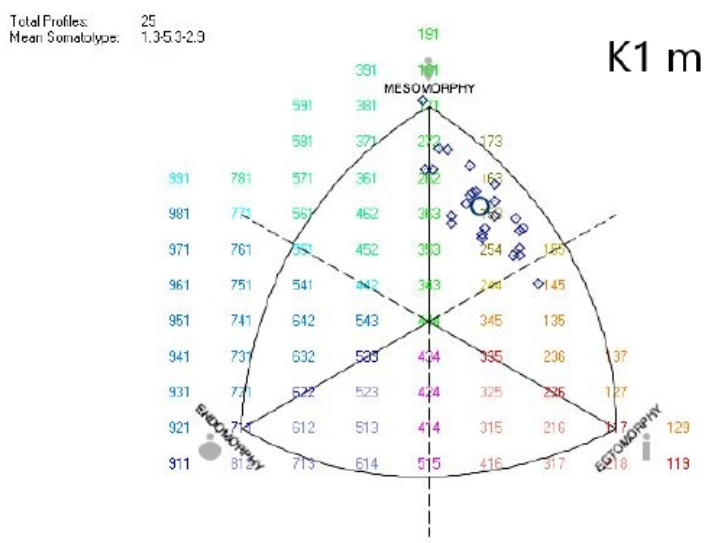

Fig. 2. Somatograph of K1 men paddlers: $\diamond$ individual somatotype; ? average somatotype.

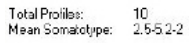

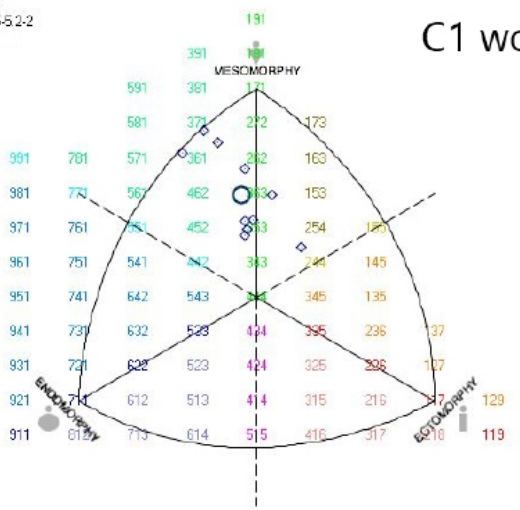

Fig. 3. Somatograph of $\mathrm{C} 1$ women paddlers: $\diamond$ individual somatotype; ? average somatotype.

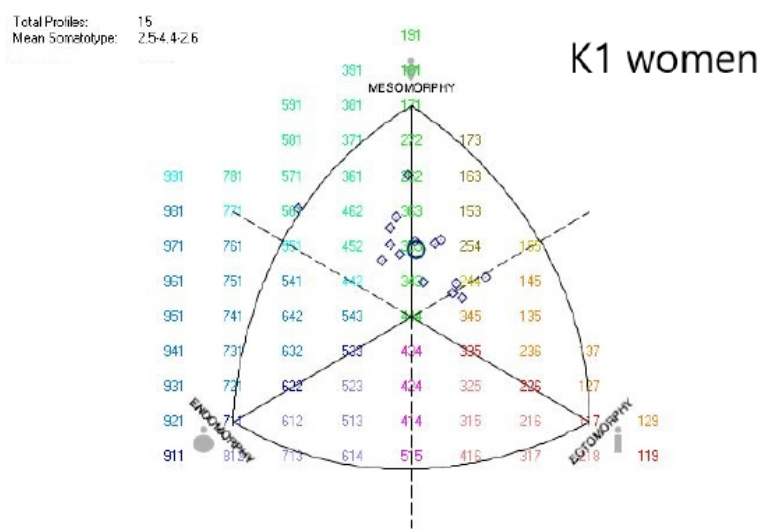

Fig. 4. Somatograph of K1 women paddlers: $\diamond$ individual somatotype; ? average somatotype. 
Table II.Comparison between male and female canoe and kayak European paddlers.

\begin{tabular}{|c|c|c|c|c|c|c|c|c|}
\hline \multirow[t]{3}{*}{ Variable } & \multicolumn{4}{|c|}{ Male paddlers $(\mathrm{n}=48)$} & \multicolumn{4}{|c|}{ Female paddlers $(\mathrm{n}=26)$} \\
\hline & \multirow{2}{*}{$\begin{array}{l}\text { Canoe } \\
(\mathrm{n}=23)\end{array}$} & \multirow{2}{*}{$\begin{array}{l}\text { Kayak } \\
(n=25)\end{array}$} & \multicolumn{2}{|c|}{ Difference } & \multirow{2}{*}{$\begin{array}{l}\text { Canœ } \\
(\mathrm{n}=11)\end{array}$} & \multirow{2}{*}{$\begin{array}{c}\text { Kayak } \\
(\mathrm{n}=15)\end{array}$} & \multicolumn{2}{|c|}{ Difference } \\
\hline & & & $\mathrm{p}$ & $\mathrm{d}$ & & & $\mathrm{p}$ & $\mathrm{d}$ \\
\hline Age (years) & $24.5 \pm 4.7$ & $24.2 \pm 5.8$ & 0.85 & 0.06 & $20.9 \pm 3.6$ & $25.9 \pm 7.7$ & 0.04 & 0.83 \\
\hline range & $18-35$ & $15-36$ & & & $17-30$ & $16-46$ & & \\
\hline Body mass (kg) & $75.6 \pm 6.2$ & $74.0 \pm 6.2$ & 0.40 & 0.25 & $59.4 \pm 4.0$ & $58.4 \pm 4.9$ & 0.60 & 0.22 \\
\hline range & $56.5-84$ & $63.1-85.3$ & & & $54.1-68.4$ & $51.4-65.8$ & & \\
\hline \multirow[t]{2}{*}{ Height $(\mathrm{cm})$} & $179.2 \pm 5.3$ & $180.3 \pm 4.8$ & 0.44 & 0.21 & $163.7 \pm 6.2$ & $164.4 \pm 4.5$ & 0.77 & 0.12 \\
\hline & $167.1-191.5$ & $172.1-193.5$ & & & $154.2-173.1$ & $157.4-171.7$ & & \\
\hline \multirow[t]{2}{*}{ Body mass index } & $23.5 \pm 1.4$ & $22.8 \pm 1.6$ & 0.10 & 0.46 & $22.3 \pm 1.2$ & $21.6 \pm 1.7$ & 0.27 & 0.47 \\
\hline & $20.2-25.9$ & $19.4-26.2$ & & & $20.2-24.1$ & $19.6-25.1$ & & \\
\hline \multirow[t]{2}{*}{ Sitting height $(\mathrm{cm})$} & $94.9 \pm 3.7$ & $94.5 \pm 3.9$ & 0.71 & 0.10 & $88.7 \pm 3.1$ & $88.2 \pm 2.8$ & 0.65 & 0.16 \\
\hline & $88.5-103$ & $83.5-102.9$ & & & $84.4-93.0$ & $83.2-95$ & & \\
\hline \multirow[t]{2}{*}{ Arm span (cm) } & $184.5 \pm 5.8$ & $184.6 \pm 6.8$ & 0.96 & 0.01 & $165.2 \pm 7.6$ & $164.6 \pm 6.3$ & 0.82 & 0.08 \\
\hline & $172.0-193.5$ & $170.0-195.6$ & & & $155.3-180$ & $152-174.1$ & & \\
\hline \multirow[t]{2}{*}{ Sitting height/body height (\%) } & $52.9 \pm 1.2$ & $52.3 \pm 1.7$ & 0.14 & 0.40 & $54.2 \pm 1.7$ & $53.6 \pm 1.1$ & 0.35 & 0.41 \\
\hline & $50.9-55.4$ & $46.2-55.8$ & & & $52.5-59.1$ & $51.2-55.3$ & & \\
\hline \multirow[t]{2}{*}{ Arm span/body height (\%) } & $103.0 \pm 2.7$ & $102.4 \pm 2.9$ & 0.46 & 0.21 & $100.9 \pm 1.8$ & $100.0 \pm 1.9$ & 0.30 & 0.48 \\
\hline & $97.8-111.1$ & $94.3-109.4$ & & & $9.2-103.9$ & $96.5-103.3$ & & \\
\hline \multirow[t]{2}{*}{ Shoulder breath (cm) } & $36.5 \pm 1.9$ & $35.5 \pm 2.1$ & 0.10 & 0.49 & $30.9 \pm 1.3$ & $30.7 \pm 0.9$ & 0.76 & 0.17 \\
\hline & $32.5-39.7$ & $32.0-39.5$ & & & $29.2-33.9$ & $29.3-33$ & & \\
\hline \multirow[t]{2}{*}{ Humerus breadth $(\mathrm{cm})$} & $7.2 \pm 0.5$ & $7.2 \pm 0.3$ & 0.90 & 0 & $6.3 \pm 0.3$ & $6.2 \pm 0.3$ & 0.26 & 0.33 \\
\hline & $6.3-8.7$ & $6.8-7.6$ & & & $5.5-6.7$ & $5.7-6.9$ & & \\
\hline \multirow[t]{2}{*}{ Femur breadth $(\mathrm{cm})$} & $10.2 \pm 0.6$ & $10.1 \pm 0.5$ & 0.54 & 0.18 & $9.3 \pm 0.3$ & $9.1 \pm 0.5$ & 0.18 & 0.48 \\
\hline & $8.7-12.0$ & $9.0-11.3$ & & & $8.7-9.8$ & $8.5-10.2$ & & \\
\hline \multirow[t]{2}{*}{ Forearm girth $(\mathrm{cm})$} & $28.8 \pm 1.4$ & $28.9 \pm 1.1$ & 0.64 & 0.07 & $25.2 \pm 0.7$ & $24.8 \pm 1.0$ & 0.21 & 0.46 \\
\hline & $25.5-31.4$ & $26.1-30.4$ & & & $24.5-26.8$ & $23.2-26.4$ & & \\
\hline \multirow[t]{2}{*}{ Flexed arm girth (cm) } & $35.7 \pm 1.9$ & $35.1 \pm 1.6$ & 0.28 & 0.34 & $30.7 \pm 1.2$ & $30.1 \pm 1.6$ & 0.32 & 0.42 \\
\hline & $31.5-38.4$ & $31.8-38.0$ & & & $28.4-33.2$ & $28.3-32.6$ & & \\
\hline \multirow[t]{2}{*}{ Chest girth (cm) } & $102.0 \pm 6.2$ & $101.2 \pm 3.9$ & 0.61 & 0.15 & $92.3 \pm 3.2$ & $90.1 \pm 3.7$ & 0.15 & 0.63 \\
\hline & $85.5-110.3$ & $91.0-107.3$ & & & $87.7-99.0$ & $81.0-97.0$ & & \\
\hline \multirow[t]{2}{*}{ Thigh girth (cm) } & $50.4 \pm 3.6$ & $50.2 \pm 3.4$ & 0.79 & 0.05 & $51.0 \pm 2.6$ & $49.5 \pm 3.5$ & 0.26 & 0.48 \\
\hline & $40.9-56.0$ & $43.2-55.1$ & & & $47.0-54.9$ & $43.1-54.2$ & & \\
\hline Calf girth $(\mathrm{cm})$ & $36.0 \pm 1.9$ & $36.2 \pm 1.8$ & 0.63 & 0.10 & $35.5 \pm 1.9$ & $34.8 \pm 2.6$ & 0.48 & 0.30 \\
\hline & $32-38.6$ & $33-41.5$ & & & $32.6-38.6$ & $30.4-40.1$ & & \\
\hline Sum of 5 skinfolds (mm) & $33.1 \pm 7.6$ & $32.6 \pm 6.6$ & 0.80 & 0.07 & $55 \pm 9.5$ & $57.2 \pm 17.4$ & 0.69 & 0.15 \\
\hline & $20-47$ & $22-43$ & & & $40-70$ & $39-95$ & & \\
\hline Body fat $(\%)$ & $8.6 \pm 3.4$ & $7.5 \pm 2.8$ & 0.24 & & $17.4 \pm 3.2$ & $16.8 \pm 5.0$ & 0.70 & 0.14 \\
\hline & $4-16.2$ & $3-13.3$ & & & $12.5-22.1$ & $10.0-26.6$ & & \\
\hline Endomorphy & $1.3 \pm 0.3$ & $1.3 \pm 0.3$ & 0.32 & 0 & $2.5 \pm 0.6$ & $2.5 \pm 0.9$ & 0.40 & 0 \\
\hline & $0.8-2.1$ & $0.6-1.8$ & & & $1.7-3.6$ & $1.3-4.8$ & & \\
\hline Mesomorphy & $5.6 \pm 0.9$ & $5.3 \pm 0.9$ & 0.14 & 0.33 & $5.2 \pm 0.9$ & $4.4 \pm 0.8$ & 0.02 & 0.93 \\
\hline & $3.9-7.8$ & $3.9-7.6$ & & & $3.9-6.6$ & $3.3-6.0$ & & \\
\hline Ectomorphy & $2.5 \pm 0.7$ & $2.9 \pm 0.8$ & 0.04 & 0.53 & $2.0 \pm 0.7$ & $2.6 \pm 0.8$ & 0.03 & 0.80 \\
\hline & $1.3-3.8$ & $1.3-4.6$ & & & $0.9-3.2$ & $1.0-3.8$ & & \\
\hline
\end{tabular}

\section{DISCUSSION}

The primary aim of this study was to determine the morphology of elite canoe slalom paddlers and to identity if morphology differences existed between kayak and canoe paddlers.
Male athletes. In comparing our results with previous research (Ridge et al.; Bíl\$ et al., 2011; Vedat, 2012; Bíl\$ et al., 2013), the morphology of canoe slalom male athletes has not changed in the last 2 or 5 decades (Sidney \& 
Shephard, 1973; Vaccaro et al., 1984; Sklad et al., 1994). The somatotype of elite USA male canoe slalom paddlers revealed a classification of ectomorphic-mesomorphy (2.9 $-5.2-2.4$ ), which is similar to the current results except that the endomorphy component islower. This is probably due to a reduction in fat contribution of contemporary paddlers. In the present study elite slalom athletes were characterized as average in body height $(\sim 180 \mathrm{~cm})$ and weight $(\sim 75 \mathrm{~kg})$, with predominantly mesomorphic somatotype, average body ratios, low body fat and specific muscularity developed mainly in the upper limbs and chest. However, there were no statistical and practical significant differences between $\mathrm{C} 1$ and $\mathrm{K} 1$ paddlers illustrating the physiognomy of $\mathrm{C} 1$ and $\mathrm{K} 1$ paddlers were similar.

In comparison with flat water canoeing (canoe sprint) athletes (Sitkowski, 2002; Ackland et al., 2003), canoe slalom athletes are smaller in height and weight. In canoe sprint athletes, Ackland et al. reported body height and body mass weight of $185 \pm 6.0 \mathrm{~cm}$ and $84.8 \pm 6.2 \mathrm{~kg}$, respectively, which is similar to that reported by Sitkowski of $185.3 \pm 1.9$ $\mathrm{cm}$ and $87.0 \pm 4.6 \mathrm{~kg}$. Canoe slalom paddlers have different somatotype in comparison to Olympic canoe sprint paddlers $(1.6-5.7-2.2)$ (Ackland et al.) and elite Lithunian canoe sprint kayakers (3.5 - 6.2 - 2.8) (Gutnik et al., 2015). Larger differences exist between elite slalom paddlers and elite rowers in body height $191.1 \pm 5.7 \mathrm{~cm}$ and body weight 87.7 $\pm 8.0 \mathrm{~kg}$ (Sklad et al.) and in junior World Championship rowers (body height $187.4 \pm 5.8$ and weight $82.2 \pm 7.4 \mathrm{~kg}$ ) (Bourgois et al., 2000). However, in comparison with rowers (Sklad et al.; Bourgois) canoe slalom paddlers have larger biceps girth $(35.4 \pm 1.8 \mathrm{~cm}$ vs. $31.9 \pm 2.1$; resp. $32.9 \pm 1.9$ $\mathrm{cm})$. In comparison to other water sports that are characterized by upper limb movement, such as, international canoe polo players, have similar anthropometric measures to canoe slalom athletes (Alves et al., 2012).

From the current results, large competitive canoe slalom males are rare. Body height and weight greater than $190 \mathrm{~cm}$ and $80 \mathrm{~kg}$, respectively is uncommon and may be an important aspect for talent identification. Greater body height is often associated with additional weight, which is likely to be detrimental to paddling performance especially when in 2005 international regulations shortened boats from $4.0 \mathrm{~m}$ to $3.5 \mathrm{~m}$ (www.canoeicf.com). Larger competitors are likely to have a disadvantage in optimizing boat hydrodynamic properties. Similar to canoe sprint performance canoe slalom paddlers have large biceps girth $(\sim 35 \mathrm{~cm})$ and low body fat $(\sim 8 \%)$ (Van Someren \& Palmer; 2003; Akca \& Muniorglu, 2008), that may correlate to slalom performance.

Female athletes. In comparing the current female K1 competitors to the 2000 Olympic canoe slalom K1 competitors (Ridge et al.), body weight (58.4 \pm 4.9 vs. $59.0 \pm 4.5 \mathrm{~kg})$, somatotype $(2.5-4.4-2.6$ vs $2.4-4.1-3)$ and biceps girth (30.1 \pm 1.6 vs. $30.1 \pm 1.0)$ were similar, but current competitors were shorter in body height (164.4 \pm 4.9 vs. $168 \pm 5$ ). However, they were of similar body height to Australian ranked paddlers $(164.4 \pm 4.9$ vs. $163.0 \pm 5.0)$ (Freeman et al., 1987).

We observed two significant differences between female canoe and kayak paddlers. Firstly, the age was significantly different $(\mathrm{p}=0.04 ; \mathrm{d}=0.83)$ with the canoe paddlers being approximately 5 years younger than kayak paddlers. The difference in age probably reflects the female canoe category being a new discipline. The first world championship was scheduled in 2011 (www.canoeicf.com) and it will be held for the first time at the Tokyo Olympic Games, which may have attracted a younger cohort. Secondly, there were significant differences in mesomorphy $(\mathrm{p}=0.02$; $\mathrm{d}=0.93)$ and ectomorphy $(\mathrm{p}=0.03 ; \mathrm{d}=0.80)$ somatotype values. Canoe paddlers were more mesomorphic and less ectomorphic in comparison with kayak paddlers, and may be explained by different demands of strength abilities.

In comparison to canoe sprint competitors (Ackland et al.) the current canoe slalom competitors were of similar height,but had lower body weight ( $58.8 \pm 4.6$ vs. $67.3 \pm 5.9$ ). Differences between canoe slalom and canoe sprint paddlers are noticeable as early as 15 years of age (Alacid et al., 2012). In addition,when comparing canoe slalom competitors to female rowers (Sklad et al.) they were smaller in stature (164.2 \pm 5.4 vs. $176.7 \pm 6.4)$, lower body mass $(58.8 \pm 4.6$ vs. $73.4 \pm 5.2)$, and similar biceps girth $(30.6 \pm 2.1$ vs. 30.5 $\pm 2.9)$ and chest girth $(90.9 \pm 3.7$ vs. $86.9 \pm 3.9)$. Despite lower body weight, this suggests that canoe slalom female competitors have well developed trunk and arm muscles, which are important physical attributes for canoe slalom.

\section{CONCLUSION}

Canoe slalom has evolved with the advancement in technology, course design, coaching, nutrition, physical and psychological training. With a greater emphasis placed on strength, speed and stability we can conclude, that anthropometric parameters of male canoe slalom paddlers have not changed through the preceding decades. Elite slalom male competitors can be characterized to having average body height $(\sim 180 \mathrm{~cm})$, average weight $(\sim 75 \mathrm{~kg})$, with ectomorphic mesomorph somatotype $(1.3-5.5-2.7)$, well developed trunk and arm muscles (biceps girth: $35.4 \pm 1.8$ ), low hypertrophy of legs and low body fat $(8 \pm 3.2 \%)$. In addition, there are no significant differences between canoe 
(C1) and kayak (K1) paddlers. For female competitors we can conclude, there has been little change in anthropometric values through the decades. However, $\mathrm{C} 1$ competitors are younger, more mesomorphic and less ectomorphic.

Generally, canoe slalom performance is likely to be disadvantaged, if the athlete has large physiognomy. Body weight over $80 \mathrm{~kg}$ in male elite paddlers is rare, similarly body height greater than $190 \mathrm{~cm}$ is equivalent for a female of greater than $70 \mathrm{~kg}$ and $180 \mathrm{~cm}$. For male and female, K1 and $\mathrm{C} 1$ we suggest developing strength without excessive leg hypertrophy. On the contrary, it is probably necessary in canoe slalom to have very well developed muscles of the chest and arms and keep body fat contribution very low.

FUNDING. This work was supported by Programme for the Development of Fields of Study at Charles University under Grant Q41 and Charles University Centre of Excellence project (UNCE/HUM/032).

COUFALOVÁ, K.; BUSTA, J.; COCHRANE, D. J. \& BÍL†, M. Características morfológicas de los remeros de canoa y kayak de slalom europeos. Int. J. Morphol., 39(3):896-901, 2021.

RESUMEN: El objetivo de este estudio fue determinar la morfología de los remeros de canoa de slalom de élite e identificar si existían diferencias morfológicas entre los remeros de kayak y canoa. El análisis incluyó un total de 74 remeros de canoa slalom que compitieron en el Campeonato de Europa de 2018. Los competidores fueron evaluados mediante una batería de dimensiones antropométricas según técnicas antropométricas estandarizadas y análisis de bioimpedancia utilizando el dispositivo octopolar multifrecuencia Tanita MC-980. Los competidores masculinos de slalom de élite se pueden caracterizar por tener una estatura corporal promedio ( $180 \mathrm{~cm})$, un peso promedio $(\sim 75 \mathrm{~kg})$, con somatotipo mesomorfo ectomorfo (1,3 - 5,5 - 2,7), músculos del tronco y del brazo bien desarrollados (circunferencia del bíceps: $35,4 \pm 1,8$ ), baja hipertrofia de piernas y baja grasa corporal $(8 \pm 3,2 \%)$. Además, no existen diferencias significativas entre los remeros en canoa $(\mathrm{C} 1)$ y kayak (K1). Para las competidoras, podemos concluir que se han observado pocos cambios en los valores antropométricos a lo largo de las décadas. Sin embargo, los competidores de C1 son más jóvenes, más mesomórficos y menos ectomórficos.

PALABRAS CLAVE: Antropometría; Impedancia bioeléctrica; Somatotipo; Kayak slalom; Slalom en canoa.

\section{REFERENCES}

Ackland, T. R.; Ong, K. B.; Kerr, D. A. \& Ridge, B. Morphological characteristics of Olympic sprint canoe and kayak paddlers. J. Sci. Med. Sport, 6(3):285-94, 2003.
Akca, F. \& Muniorglu, S. Anthropometric-somatotype and strength profiles and on-water performance in Turkish elite kayakers. Int. J. Appl. Sports Sci., 20(1):22-34, 2008

Alacid, F.; Muyor, J. M.; Vaquero, R. \& López-Miñarro, P. A. Morphological characteristics and maturity status of young female sprint and slalom kayakers. Int. J. Morphol., 30(3):895-901, 2012.

Alves, C. R. R.; Pasqua, L.; Artioli, G. G.; Roschel, H.; Solis, M.; Tobias, G.; Klansener, C.; Bertuzzi, R.; Franchini, E.; Lancha Junior, A. H.; et al. Anthropometric, physiological, performance, and nutritional profile of the Brazil National Canoe Polo Team. J. Sports Sci., 30(3):305-11, 2012.

Bílł, M.; Baláš̌, J.; Martin, A. J.; Cochrane, D.; Coufalová, K. \& Süss, V. Effect of paddle grip on segmental fluid distribution in elite slalom paddlers. Eur. J. Sport Sci., 13(4):372-7, 2013.

Bílł, M.; Süss, V. \& Buchtel, M. Selected somatic factors of white water canoeists. J. Outdoor Act., 5(2):30-42, 2011.

Bourgois, J.; Claessens, A. L.; Vrijens, J.; Philippaerts, R.; Van Renterghem, B.; Thomis, M.; Janssens, M.; Loos, R. \& Lefevre, J. Anthropometric characteristics of elite male junior rowers. Br. J. Sports Med., 34(3):2136; discussion 216-7, 2000.

Busta, J.; Kinkorová, I.; Tufano, J. J.; Bílł, M. \& Suchł, J. Anthropometric and somatotype differences between $\mathrm{C} 1$ paddlers who were and were not selected for the Czech national team. Acta Univ. Carol. Kinanthropologica, 54(1):53-61, 2018.

Freeman, P. L.; Chennels, M. H. D.; Sandstrom, E. R. \& Briggs, E. R. Specificity in Performance: Determination of the Anthropometric and Physiological Characteristics of Canoeists (National Sports Science Research Program). Canberra, Australian Sport Commission, 1987.

Gutnik, B.; Zuoza, A.; Zuoziene', I.; Alekrinskis, A.; Nash, D. \& Scherbina, S. Body physique and dominant somatotype in elite and low-profile athletes with different specializations. Medicina (Kaunas), 51(4):247-52, 2015.

Heath, B. H. \& Carter, J. E. L. Somatotyping - Development and Applications. Cambridge (UK), Cambridge University Press, 1990.

Hopkins, W. G. A Scale of Magnitudes for Effect Statistics. In: Hopkins, W. G. A New View of Statistics. Web Site. 2006. Available from: http:// sportsci.org/resource/stats/effectmag.html

Lohman, T.; Martorell, R. \& Roche, A. F. Anthropometric Standardization Reference Manual. Champaign (IL), Human Kinetics, 1988.

Ridge, B. R.; Broad, E.; Kerr, D. A. \& Ackland, T. R. Morphological characteristics of Olympic slalom canoe and kayak paddlers. Eur. J. Sport Sci., 7(2):107-13, 2007.

Sidney, K. \& Shephard, R. J. Physiological characteristics and performance of the white-water paddler. Eur. J. Appl. Physiol., 32:55-70, 1973.

Sitkowski, D. Some indices distinguishing Olympic or world championship medallists in sprint kayaking. Biol. Sport, 19(2):133-47, 2002.

Sklad, B.; Krawczyk, B. \& Majle, B. Body build profiles of male and female rowers and kayakers. Biol. Sport, 11(4):249-56, 1994.

Vaccaro, P.; Gray, P. R.; Clarke, D. H. \& Morris, A. F. Physiological characteristics of world class white-water slalom paddlers. Res. Q. Exerc. Sport, 55(2):206-10, 1984.

van Someren, K. \& Palmer, G. S. Prediction of 200-m sprint kayaking performance. Can. J. Appl. Physiol., 28(4):505-17, 2003.

Vedat, A. Somatotypes of male whitewater canoe athletes of the Turkish National Canoe Team. Educ. Res. Rev., 7(24):526-31, 2012.

\section{Corresponding author:}

Klára Coufalová

Faculty of Physical Education and Sport

Charles University

José Martího 31

16252 Prague

CZECH REPUBLIC

\section{E-mail: coufalova@ftvs.cuni.cz}

Received: $19-03-2021$

Accepted: 19-04-2021 